\title{
DINAMIKA PERKEMBANGAN ILMU DALAM ISLAM SERTA STATUSNYA DALAM PERKEMBANGAN PERADABAN MODERN
}

\author{
M. Zainal Abidin \\ Program Studi Filsafat Islam Program Pascasarjana IAIN Antasari \\ Jl. A. Yani Km. 4,5 Banjarmasin \\ Diterima 15 Agustus 2011/Disetujui 15 Nopember 2011
}

\begin{abstract}
This paper studies about the history and the dynamic of knowledge developing in Islam. The glorious of Islamic civilization which were signed by the advance of knowledge developing around 7 th to 13 th centuries was not something hapened by an accident, but through long process and it was related with the prestige of muslims in field of knowledge. In the centuries that called as the golden age of Islam, muslim civilization become the central of world civilization and give the high contribution in emerging the modern western civilization. While, in next phase when muslim become underdeveloping countries it was also related with the status on knowledge that marginalized and stagnanted in inmuslim world. There were many theories and argumentations from many experts that stated about the factors caused the falling of muslim. The falling of muslim people in same time is also the problem of mainkind together, because the western modern civilization was ambigious in understanding the concept of knowledge.
\end{abstract}

Kata kunci: kemajuan, kemunduran, status ilmu, peradaban modern

\section{Pendahuluan}

Umat Islam, sebagaimana dikemukakan banyak ahli sejarah, pernah menorehkan kegemilangan peradaban pada sekitar kurun ke-7 sampai dengan ke-13 Masehi, bahkan beberapa abad setelahnya pun pengaruh itu masih sangat terasa kuat di Eropa. Pada abad-abad yang disebut sebagai masa keemasan Islam (the golden age of Islam) ini, peradaban muslim menjadi mercusuar peradaban dunia dan pelopor kecemerlangan di bidang ilmu, dengan jumlah perpustakaan beserta koleksinya yang sangat banyak. ${ }^{1}$

${ }^{1}$ Untuk diskusi lebih lanjut tentang persoalan ini, lihat misalnya Philip K. Khitti, History of the Arab from the Earliest Times to the Present (New York: St. Martin Press, 1968), h. 365- 
Pada masa kejayaan itu, dunia Islam dikenal dengan para ilmuwan yang menguasai beragam displin keilmuan. Di bidang teologi terdapat nama al-Asy'ari (w. 935) dan al-Maturidi (w. 944); di bidang sastra ada nama alJahiz (w. 780) dan Ibn Qutaybah (w. 828); di bidang sejarah dan geografi muncul nama al-Baladhuri (w. 820) dan al-Ya'kubi (w. 897); di bidang sufisme dikenal sosok al-Muhasibi (w. 857), Abu Yazid al-Bisthami (w. 875), dan al- Hallaj (w. 922); di bidang kedokteran mengemuka nama-nama seperti al-Razi (w. 923-32) dan Ibn Sina ( w. 1037); di bidang matematika dan astronomi tampil al-Khawarizmi (w. setelah 846) dan Ibn Haitsam (w. 1039); dan di bidang filsafat ada al-Kindi, al-Farabi (870), dan Ibn Sina (980). Merekalah sebagian para ilmuwan yang menandai kecemerlangan dan supremasi ilmu peradaban muslim.

Sebagai gambaran pencapaian bidang ilmu dan status yang istimewa pada masa kejayaan peradaban Islam, pada kurun awal $750 \mathrm{M}$, Khalifah Bani Abbasiyah, Harun al-Rasyid, telah mendirikan observatorium di Damaskus, di mana kajian astronomi dan berbagai eksperimen dilakukan. Banyak ahli astronomi muslim seperti al-Farghani (850 M), al-Battani (858929 M), dan Tsabit bin Qurra (826-901 M) berhasil melakukan eksperimen dan merumuskan teori sehingga pandangan kosmologi Islam lebih maju. Ada juga observatorium seperti di Raqqa yang dibangun oleh al-Battani; di Syiraz yang dibangun oleh Abdurrahman al-Sufi; di Hamadan yang dipakai oleh Ibnu Sina; di Maragha yang dibangun oleh Hulagu Khan pada tahun 1261 M dan digunakan oleh Nasr al-Din al-Thusi. Selain itu, ada juga di Samarkhanda yang dibangun oleh Ulugh Beh di mana para ilmuwan seperti Qadizallah, Ali Qush, dan Ghiyats al-Din al-Khasyani menghasilkan banyak kajian astronomi dan eksperimen. ${ }^{2}$

406; De Lacy O'Leary, DD., Arabic Thought and Its Place in History (London: Routledge \& Kegan Paul Ltd., 1968), h. 109, 136, dan 181; dan Seyyed Hossein Nasr and Oliver Leaman (eds.), History of Islamic Philosophy (London and New York: Routledge, 1996), h. 165-364.

${ }^{2}$ Lihat Umar A. M. Kasule, "Revolusi Ilmu Pengetahuan: Kenapa terjadi di Eropa Bukan di Dunia Muslim?” dalam majalah ISLAMLA, Tahun 1, No. 3/September-Nopember 2004, 83-84. 


\section{Faktor-faktor Pemicu Kejayaan Ilmu}

Kemajuan di bidang ilmu yang dicapai oleh umat Islam selama berabad-abad tersebut tentu bukan sesuatu yang datang tiba-tiba, tetapi melalui proses yang melibatkan banyak faktor yang mendukung berbagai pencapaian tersebut. Ada banyak faktor yang dapat menjelaskan cikal bakal lahirnya kejayaan ilmu di dunia muslim. Beberapa yang terpenting dijelaskan sebagai berikut.

Pertama, motivasi agama. Sebagaimana diketahui, banyak ayat Alquran dan hadis Nabi yang mendorong umat Islam agar membaca, melakukan observasi, melakukan eksplorasi, melakukan ekspedisi, dan sejenisnya, yang menjadi sumber inspirasi dan motivasi terbesar bagi umat Islam untuk senantiasa mengkaji dan mengembangkan ilmu. Seorang sarjana muslim kontemporer terkemuka, yang pernah meraih penghargaan Nobel di bidang fisika, Profesor Abdus Salam, memberikan ilustrasi terkait motivasi yang mendorong pengembangan sains di masa keemasan Islam. Menurutnya, alasan mengapa umat Islam mencari dan mengembangkan sains, yaitu karena mereka mengikuti perintah yang diulang-ulang Alquran dan Rasulullah. Dengan mengutip pandangan Muhammad Ijazul Khatib, Salam menyatakan:

Tak ada yang lebih menekankan pentingnya sains daripada kenyataan bahwa berbeda dengan bagian legislatif yang hanya terkandung dalam 250 ayat saja, 750 ayat Alquran -hampir seperdelapan seluruh isinya- menegur orang-orang mukmin untuk mempelajari alam semesta, untuk berpikir, untuk menggunakan penalaran yang sebaik-baiknya, dan untuk menjadikan kegiatan ilmiah ini sebagai bagian yang tak terpisahkan dari kehidupan umat. ${ }^{3}$

Begitu gencar ayat-ayat tentang ilmu ini didengungkan, sehingga mencari atau menuntut ilmu diyakini sebagai kewajiban atas setiap individu muslim, dengan implikasi dosa bagi mereka yang tidak melakukannya. Pada tataran praktis, doktrin ini membawa dampak positif. Ia mendorong dan mempercepat terciptanya masyarakat ilmu (knowledge society) dan budaya ilmu (knowledge culture).

${ }^{3}$ Abdus Salam, Sains dan Dunia Islam, terj. A. Baiquni (Bandung: Penerbit Pustaka, 1983), h. 16. 
Kedua, dukungan dan perlindungan politis dari penguasa. Dukungan dan perlindungan politis dari penguasa saat itu juga turut berperan penting, mengingat implikasi finansial serta sosialnya. Konflik antar penguasa muslim saat itu tidak lantas kemudian ikut membelenggu aktivitas para ilmuwan. Mereka dengan bebas dapat berpindah patron kepada penguasa yang sedang dalam konflik politik, dengan suatu keyakinan bahwa mereka akan diterima dengan penuh penghormatan karena penghargaan masingmasing penguasa muslim tersebut terhadap ilmu. Para pencari ilmu ataupun cendekiawan dengan leluasa dan aman bepergian dan merantau ke pusatpusat pendidikan dan keilmuan, dari Seville ke Baghdad, dari Samarkand ke Madinah, dari Isfahan ke Kairo, atau dari Yaman ke Damaskus. Ini belum termasuk mereka yang menjelajahi seluruh pelosok dunia Islam semisal Ibnu Jubayr (w. 1217 M) dan Ibnu Bathutah (w. 1377 M). ${ }^{4}$ Para ilmuwan seperti Ibnu Sina, Ibnu Thufail, Nashiruddin al-Thusi, dan lain-lain biasa berpindah dari satu tempat ke tempat lain mengikuti patronnya. ${ }^{5}$

Sinergisitas yang bagus antara penguasa (pemerintah) dengan para ilmuwan, yang disertai dengan tradisi ilmiah atau budaya ilmu yang sangat kuat serta kesejahteraan warga yang memadai, telah menjadikan pencapaian yang luar biasa dari bangsa Arab Badui yang dahulunya sangat terkebelakang dan tidak pernah diperhitungkan dalam percaturan peradaban dunia, secara tiba-tiba bangkit menjadi pemimpin peradaban dan memberikan berhasil memberikan sumbangan yang sangat berharga pada berbagai bidang keilmuan seperti astronomi, matematika, kimia, fisika, hingga filsafat, yang pada gilirannya menjadi tonggak kemajuan dan pencapaian dunia modern saat ini.

Ketiga, faktor ekonomi. Stabilitas ekonomi memiliki peran yang tidak kalah penting dalam membangun lingkungan ilmu yang kondusif. Kesejahteraan dan kemakmuran yang dirasakan masyarakat muslim pada masa itu membuka peluang bagi individu untuk mengembangkan diri

${ }^{4}$ Perbincangan sekitar pengembaraan mencari ilmu yang dilakukan oleh para intelektual muslim pada saat itu dapat dilihat pada kajian Ian R. Netton, Seek Knowledge: Thought and Travel in the House of Islam (Richmond: Curzon Press, 1996); lihat juga idem, Golden Roads: Migration, Pilgrimage, and Travel in Medievel and Modern Islam (Richmond: Curzon Press, 1993).

${ }^{5}$ Diskusi mengenai pentingnya patron ini, lihat Toby E. Huff, The Rise of Early Modern Science: Islam, China, and the West (Cambridge: Cambridge University Press, 1993). 
(aktualisasi diri) dan mencapai apa yang diinginkan. Salah satu bentuk aktualisasi yang muncul adalah keterlibatan mereka di bidang pengembangan ilmu. ${ }^{6}$

Keempat, faktor konflik. Luasanya teritorial kekuasaan Islam menyebabkan kekuasaan tidak berada pada satu tangan. Ada banyak kerajaan atau kesultanan Islam, yang terkadang antara mereka terlibat konflik bahkan peperangan. Dalam sejarah Islam, konflik internal bukanlah sesuatu yang baru lahir belakangan. Pada masa sahabat, peperangan juga telah terjadi semisal Perang Jamal ataupun Perang Shiffin. Demikian juga pada masa-masa sesudahnya, peperangan antarumat bukanlah sesuatu yang aneh. Bermula dari konflik politik, kemudian masuk ke dalam ranah keagamaan. Lahirnya aliran-aliran kalam dalam Islam merupakan contoh kuat dari konflik politik yang merambah ke ranah keagamaan dan melahirkan karya-karya kalam.

Pengaruh konflik dalam bidang ideologi juga diyakini memberikan pengaruh kuat dalam melahirkan berbagai corak tradisi intelektual Islam. Al-Jabiri misalnya membagi tiga wilayah utama kekuasaan dunia Islam yang ternyata berhubungan erat dengan model epistemologi yang dikembangkan. Ada tiga model epistemologi yang ungkapkannya, yakni: bayani, irfani, dan burhani. $^{7}$

Epistemologi bayani beranggapan bahwa sumber ilmu pengetahuan adalah wahyu (teks) atau penalaran dari teks. Epistemologi bayani merupakan suatu cara untuk mendapatkan pengetahuan dengan berpijak pada teks, baik secara langsung maupun tidak langsung. Tradisi ini berkembang pada kekuasaan Islam Sunni bagian Timur. ${ }^{8}$ Epistemologi irfani beranggapan bahwa ilmu pengetahuan adalah kehendak. Epistemologi ini memiliki metode yang khas dalam mendapatkan pengetahuan, yaitu kasyf. Tradisi ini dipelihara pada kekuasaan Islam Syi'ah. ${ }^{9}$ Epistemologi burhani ber-

${ }^{6}$ Lihat juga Syamsuddin Arif, "Sains di Dunia Muslim: Telaah Historis Sosilogis", dalam Majalah Pemikiran dan Peradaban Islam ISLAMLA, Tahun II, No. 6/Juli-September 2005, h. 89-90.

${ }^{7}$ Lihat Muhammad Abid al-Jabiri, Bunyat Aqli al-Arabî: Dirâsat Ta'liliyyât Naqdiyyât Li Nadhami al-Ma'rifah fi al-Tsaqâfah al-'Arabiyyat, (Beirut: Markas al-Wahdah al-'Arabiyyah, 1990), h. 556 .

${ }^{8}$ al-Jabiri, Bunyat Aqli al-Arabî.

'al-Jabiri, Bunyat Aqli al-Arabî, h. 252. 
pandangan bahwa sumber ilmu pengetahuan adalah akal. Akal menurut epistemologi ini mempunyai kemampuan untuk menemukan berbagai pengetahuan, bahkan dalam bidang agama sekalipun akal mampu untuk mengetahuinya, seperti masalah baik dan buruk. Tradisi ini muncul pada kekuasan Islam di wilayah Barat. ${ }^{10}$ Dengan pembagian pada tiga ranah epistemologi ini, al-Jabiri bermaksud menjelaskan bahwa warisan khazanah intelektual Islam sangat terkait erat dengan corak atau bias epistemologi yang dianut.

\section{Posisi Ilmu pada Masa Kejayaan Islam}

Lahirnya tradisi keilmuan di dunia Islam sebagaimana disinyalir Adi Setia dapat dilihat pada dua perkembangan utama. Pertama, perkembangan internal berupa proses peralihan bangsa Arab dari pandangan hidup (worldview) keberhalaan tak rasional kepada akidah atau pandangan ketauhid-an rasional, karena pengaruh sistem nilai dan sistem berpikir anjuran Alquran yang menjelma dalam kata dan pribadi Nabi, yakni sunnah kenabian. Kedua, berupa pengambilalihan ilmu-ilmu sains dan filsafat dari peradaban-peradaban bertetangga yang sudah matang tahap keilmuannya, seperti Yunani di Syams dan Mesir yang ditakluki, Persia, dan India. ${ }^{11}$

Semangat umat yang sangat menghargai ilmu pada masa kejayaan Islam dapat diamati pada masa kekuasaan Bani 'Abbasiyah, khususnya pada waktu Khalifah al-Ma'mun (berkuasa sejak 813-833 M). Penerjemahan buku-buku non-Arab ke dalam bahasa Arab terjadi secara besar-besaran dari awal abad kedua hingga akhir abad keempat hijriyah. Perpustakaan besar Bait al- Hikmah didirikan oleh Khalifah al-Ma'mun di Baghdad yang kemudian menjadi pusat penerjemahan dan intelektualitas.

Buku-buku yang diterjemahkan terdiri dari berbagai bahasa, mulai dari bahasa Yunani, Suryani, Persia, Ibrani, India, Qibti, Nibti, dan Latin. Di antara banyak pengetahuan dan kebudayaan yang diterjemahkan ke dalam bahasa Arab, karya-karya klasik Yunani adalah yang paling banyak

${ }^{10}$ al-Jabiri, Bunyat Aqli al-Arabî, h. 383-384.

${ }^{11}$ Lihat Adia Setia, "Melacak Ulang Asal-Usul Filsafat dan Sains Yunani”, dalam Majalah Pemikiran dan Peradaban Islam ISLAMIA, Vol. III, No. 1, 2006, h. 112-113. 
menyita perhatian, khususnya karya-karya filsuf besar Yunani seperti Plato dan Aristoteles. ${ }^{12}$

Dalam persoalan penerjemahan ini sebagaimana dikemukakan oleh Jamil Saliba, ada dua motivasi yang mendorong gerakan penerjemahan yang sudah dimulai sejak zaman Bani Umayah dan kemudian menemukan puncaknya pada dinasti Bani 'Abbasiyah, yakni motivasi praktis dan motivasi kultural. Pada motivasi praktis, ada kebutuhan pada bangsa Arab saat itu untuk mempelajari ilmu-ilmu yang berasal dari luar Islam seperti kimia, kedokteran, fisika, matematika, dan falak (astronomi), yang secara praktis dianggap dapat membantu meringankan urusan-urusan yang berkenaan dengan hajat hidup umat Islam ketika itu. Ilmu-ilmu ini secara praktis memang langsung berhubungan dengan hajat hidup umat Islam dalam menyelesaikan masalah-masalah seperti penentuan waktu shalat, hukum faraidh (pembagian harta waris), masalah kesehatan, dan lain sebagainya. ${ }^{13}$

Pada motivasi kultural, ada kebutuhan pada masyarakat Islam untuk mempelajari kebudayaan-kebudayaan Persia dan Yunani untuk menguatkan sistem hukum Islam dan menangkal akidah yang datang dari luar Islam. Ketika terjadi gelombang kebudayaan luar dalam dunia Islam yang meliputi akidah kaum Majusi dan kaum Dahriah, Kekhalifahan 'Abbasiyah mengangap perlu bagi kaum muslim untuk mempelajari ilmu-ilmu logika serta sistem berpikir rasionalis lainnya untuk menangkal akidah yang datang dari luar itu. Umat Islam dianjurkan untuk mempelajari logika Aristoteles, agar dapat berdebat dengan keyakinan yang datang dari luar. ${ }^{14}$

Proses penerjemahan yang berlangsung sekitar dua abad ini telah membawa pengaruh yang besar bagi umat Islam saat itu. Hal ini karena proses penerjemahan menjadi mediator dalam dialog antara kebudayaan

${ }^{12}$ Untuk kebudayaan Persia dan India, terjemahan umumnya hanya meliputi masalahmasalah astronomi, kedokteran, dan sedikit tentang ajaran-ajaran agama. Al-Biruni (w. 1048) dalam Tahqîq ma li al-Hind min Maqulah (Kebenaran Ihwal Kepercayaan Rakyat India) menguraikan kepercayaan fundamental orang-orang Hindu dan menyejajarkannya dengan filsafat Yunani. Sementara, Ibnu al-Muqaffa' (w. 759) dalam Kalîlah wa Dimnah (Fabel-fabel Tentang Guru) diterjemahkan dari bahasa Sansekerta yang merupakan pengetahuan sastra Persia.

${ }^{13}$ Lihat Jamil Shaliba, al-Falsafah al-'Arabiyah (Beirut: Dâr al-Kitâb al-Lubnani, 1973), h. 107.

${ }^{14}$ Ibid. 
pengetahuan pra-Islam dengan umat Islam yang sedang haus ilmu. Khazanah kebudayaan besar Yunani, Persia, dan India yang mulai ditinggalkan di negerinya sendiri, mendapatkan sambutan yang sangat luar biasa di dunia Islam. Sampai-sampai seorang khalifah bersedia membayar sebuah buku yang sudah diterjemahkan dengan nilai emas seberat buku tersebut. Selain itu, motivasi ini juga dilatarbelakangi oleh keyakinan umat Islam saat itu bahwa peradaban hanya dapat dibangun dengan ilmu yang kuat. Untuk melakukan proses tersebut, Islam yang baru saja berdiri tidak dapat melakukan tugas itu sendirian, melainkan harus dibantu dengan khazanah kebudayaan besar yang telah ada sebelumnya.

Perpaduan antara semangat umat Islam dengan kebudayaan pra-Islam melahirkan sebuah sintesa yang tidak sederhana. Sintesa yang dihasilkan tentunya bukan hanya sekadar penjiplakan ilmu sebelumnya, yang kemudian diberi label Islam karena telah diterjemahkan ke dalam bahasa Arab. Lebih dari itu, sintesa ini juga meliputi proses reproduksi yang banyak dilakukan oleh para ilmuwan muslim saat itu.

Pada masa kejayaannya, umat Islam senantiasa bersikap terbuka terhadap pemikiran dan tradisi yang berbeda di luarnya, bahkan tak jarang memberikan apresiasi yang sangat bagus, dengan mengadopsi dan menjadikannya sebagai bagian yang integral dari Islam itu sendiri. Refleksi dan manifestasi kosmopolitanisme Islam ini bahkan bisa dilacak dari sejarah paling awal kebudayaan Islam pada masa kehidupan Rasulullah saw. hingga generasi-generasi sesudahnya, baik dalam format non material seperti konsep-konsep pemikiran, maupun yang material seperti seni arsitektur bangunan dan sebagainya. ${ }^{15}$

Selain itu, yang lebih mencengangkan lagi, meski harus diakui bahwa unsur Arab memiliki keistimewaan di dalam Islam, ${ }^{16}$ akan tetapi sebagaimana dinyatakan Ibnu Khaldun, bahwa mayoritas ulama dan cendekiawan dalam agama Islam adalam 'ajam (non Arab), baik dalam ilmu-ilmu syari'at

${ }^{15}$ Untuk ilustrasi, lihat Yusuf al-Qardhawi, Madkhal li al-Dirâsah al-Islâmiyyah (Beirut: Dâr al-Fikr, 1993), h. 253; Badri Yatim, "Dari Mekah ke Madinah", dalam Taufik Abdullah, Ensiklopedi Tematis Dunia Islam (Jakarta: PT. Ichtiar baru Van Hoeve, 2002), h. 29-30.

${ }^{16}$ Tentang keistimewaan hubungan Islam dengan unsur Arab, lihat Muhammad Imarah, al-Islâm wa al-'Urûbah (Kahirah: al-Haihal al-Mashriyyah al-'Ammah li al-Kitab, 1996), h. 11-12. 
maupun ilmu-ilmu akal. Kalaupun di antara mereka orang Arab secara nasab, tetapi mereka 'ajam dalam bahasa, lingkungan pendidikan, dan gurunya. ${ }^{17}$

Para sarjana muslim pada masa kejayaan itu dengan leluasa menyerap, kemudian memodifikasi tradisi filsafat sains yang berangkat dari postulatpostulat Alquran dengan mengetengahkan tradisi berpikir empirikal-eksperimental. Usaha tersebut dilakukan dengan mendayagunakan perangkatperangkat intelektual sebagai jalan mencari jawab tentang hakikat realitas, baik yang nyata maupun yang gaib. Dari revolusi filsafat di tangan kaum muslimin itu, lahirlah konsep ilmu atau sains yang tegak di atas postulatpostulat Qur'ani. ${ }^{18}$

Metode eksperimen dikembangkan oleh sarjana-sarjana Muslim pada abad keemasan Islam, ketika ilmu dan pengetahuan lainnya mencapai kulminasi antara abad ke-9 sampai ke-12. Semangat mencari kebenaran yang dimulai oleh pemikir-pemikir Yunani dan hampir padam dengan jatuhnya Kekaisaran Romawi dihidupkan kembali dalam kebudayaan Islam. "Jika orang Yunani adalah bapak metode ilmiah," simpul H.G. Wells, "maka orang Muslim adalah bapak angkatnya." Dalam perjalanan sejarah, lewat orang Muslimlah, dan bukan lewat kebudayaan Latin, dunia modern sekarang ini mendapatkan kekuatan dan cahayanya. ${ }^{19}$

\section{Transmisi Ilmu dari Dunia Muslim ke Barat}

Melalui berbagai kajian terhadap akar genealogis dan asal muasal kemajuan peradaban Barat dewasa ini, banyak pakar sejarah yang menyatakan bahwa pencapaian yang diraih Barat, tidak akan pernah seperti sekarang ini tanpa ada pengaruh dan kontribusi yang diberikan Islam, khususnya pada masa-masa kejayaannya. Philip K. Hitti misalnya memaparkan bagaimana peran dari orang-orang Islam, khususnya yang ada di Spanyol dalam upaya melahirkan pembaruan di Eropa.

\footnotetext{
${ }^{17}$ Lihat Ibnu Khaldun, Muqaddimah Ibnu Khaldun (Beirut: Dâr al-Fikr, 1989), h. 543.

${ }^{18}$ Lihat Syamsul Arifin dkk., Spritualisasi Islam dan Peradaban Masa Depan (Yogyakarta: SIPRESS, 1996), h. 108.

${ }^{19}$ Lihat Jujun S. Suriasumantri, Filsafat Ilmu Sebuah Pengantar Populer (Jakarta: Pustaka Sinar Harapan, 1988), h. 115.
} 
Orang Islam Spanyol mengarang salah satu daripada bab-bab yang gemilang dalam sejarah intelek pada zaman pertengahan Eropa. Di antara pertengahan abad ke-8 dan permulaan abad ke-13, orang Arab merupakan pemimpin utama dalam budaya dan peradaban seluruh dunia. Kedua bidang ini merupakan perantara untuk memulih, menambah, dan menyebar sains dan falsafah kuno yang telah memungkinkan pembaruan di Eropa Barat. $^{20}$

Sains Islam sebagaimana juga dinyatakan Seyyed Hossein Nasr mempunyai pengaruh besar baik di Barat. Rentang antara abad ke-11 sampai dengan abad ke-13 Masehi, banyak karya-karya besar sains Islam diterjemahkan ke dalam bahasa Latin, terutama di Spanyol, Sisilia, dan Italia. Beberapa ilmuwan muslim seperti Ibnu Sina dan al-Razi menjadi nama yang sangat disegani di Barat. ${ }^{21}$

Pengaruh yang diberikan peradaban muslim ini mencakup berbagai bidang keilmuan. Dalam bidang matematika, al-Khwarizmi dan yang lainnya diajarkan di berbagai universitas Barat selama beberapa abad. Tabel-tabel astronomi yang dirakit di Barat dibuat berdasarkan zijes muslim. Karangan-karangan tentang aljabar yang ditulis kemudian pada abad pertengahan dan masa renaisans sebagian besar berdasar pada karya Khayyam. Karya-karya alkimia dan kimia secara persis dipergunakan, karena tidak ada perbendaharaan kata Latin yang sesuai dengan bidang ini. Namun, yang tidak kalah penting bahwa hampir seluruh risalah sains Islam yang diterjemahkan ke dalam bahasa Latin berasal dari bahasa Arab. ${ }^{22}$

Proses penerjemahan buku-buku berbahasa Arab ke dalam bahasa Latin hanyalah salah satu bentuk dari pengaruh yang diberikan oleh dunia muslim. Menurut kajian yang dilakukan Salma Khadra Jayyusi, setidaknya ada lima model transformasi kultur Islam ke dalam kebudayaan Barat, yaitu: (1) melalui cerita-cerita dan syair-syair yang ditransmisikan secara oral oleh orang-orang Barat; (2) dengan cara kunjungan atau turisme. Pada abad ke-7 M, Cordova adalah ibukota negara Islam yang menonjol dan

\footnotetext{
${ }^{20}$ Philip K. Hitti, The Arabs: A Short History, h. 174-175.

${ }^{21}$ Seyyed Hossein Nasr, A Young Muslim's Guide to The Modern World (Chicago: Kazi Publication, Inc. 2003), h. 86-87.

${ }^{22}$ Philip K. Hitti, The Arabs: A Short History, h. 108.
} 
merupakan kota paling berperadaban di Eropa, dan karena itu orangorang Eropa berduyun-duyun mengunjungi tempat ini untuk belajar dari peradaban Islam; (3) melalui hubungan perdagangan dan politik resmi utusan yang dikirim dari kerajaan-kerajaan di Eropa ke dunia muslim; (4) dengan cara menerjemahkan karya-karya ilmiah orang Islam. Monastrimonastri Eropa, khususnya Santa Marie de Rippol, pada abad ke-12 dan ke-13 M memiliki ruangan penyimpan mansukrip bagi sejumlah besar karya-karya ilmiah orang Islam untuk mereka terjemahkan; dan (5) melalui pendirian sekolah bagi para penerjemah di Toledo oleh raja-raja Eropa dalam rangka kelancaran proses penerjemahan, tepat sesudah pasukan Kristen merebut kembali kota tersebut pada tahun 1085. Tujuannya adalah untuk menggali ilmu Islam yang terdapat pada perpustakaan-perpustakaan bekas daerah kekuasaan muslim tersebut. ${ }^{23}$

Sementara itu, Umar A.M. Kasule menyatakan bahwa setelah mewarisi paradigma keilmuan dasar dari orang muslim, orang Barat kemudian membekali dirinya dengan ilmu yang dengan segala cara bertransformasi agar siap menyambut revolusi sains. Proses terpenting dari transformasi keilmuan ini adalah institusionalisasi. Orang Eropa membentuk institusi universitas. Aktivitas ini menjadi fondasi sains sejak abad pertengahan hingga sekarang ini.

Di universitas, ilmu dan sains diatur dengan baik. Filsafat natural lebih unggul di Barat karena dapat menyerap karya-karya filsafat agung ke dalam ilmu. Selain itu, dalam kelembagaan ini diperoleh kebebasan yang dinikmati oleh pengajar dan pelajar di universitas. Di samping penerjemahan dan universitas, faktor lainnya yang memungkinkan majunya tradisi keilmuan di Eropa adalah munculnya golongan ahli filsafat-teologi. Mereka berperan utama dalam menyokong filsafat sebagai lapangan studi yang penting. Pada dasarnya merekalah yang menyelamatkan filsafat dari kemarahan gereja. Dibandingkan kolega mereka di dunia Islam yang "memusuhi" filsafat, ahli teologi di Barat mencari kompromi antara filsafat dan teologi. Bahkan, jika perlu teologi memakai ide-ide filsafat.

\footnotetext{
${ }^{23}$ Salma Khadra Jayyusi sebagaimana dikutip oleh Hamid Fahmy Zarkasyi, "Akar Kebudayaan Barat”, dalam majalah ISLAMIA, Vol. III, No. 2, Januari-Maret 2007, h. 24.
} 
Fakta pertautan filsafat dan ahli teologi inilah yang menjelaskan paradoks mengapa filsafat Aristoteles yang tidak disukai Gereja dapat tumbuh di universitas abad pertengahan, padahal saat itu universitas di bawah perlindungan Gereja. Begitu menyokong filsafat, para ahli teologi ini memberikan fasilitas studi di universitas. Bahkan, mereka menjadikan filsafat menjadi syarat bagi pelajar yang ingin meraih gelar teologi dan diharuskan mendapatkan nilai tinggi dalam filsafat. Maka wajar kemudian apabila para saintis terkenal masa itu pada saat yang sama juga ahli teologi. Sosok seperti Magnus, Robert Grosseteste, Joh Pecham, Theodoric dari Freiberg, Thomas Brandwardine, Nicole Oresme, dan Henry dari Langenstein mewakili fakta ini. ${ }^{24}$

Suasana damai di Eropa menjelang abad ke-17 Masehi sangat mendukung aktivitas keilmuan di sana. Stabilitas sosial dan politik juga berarti stabilitas mental, yang tanpanya kemajuan intelektual tidak akan terwujud. Eropa Barat tidak pernah mengalami teror seperti dialami dunia muslim yang dilakukan bangsa Mongol dan pasukan Salib. Kemakmuran ekonomi juga berkaitan erat dengan suasana damai di Eropa. Kota-kota di sana pada umumnya lebih makmur dibandingkan dengan kesultanan di dunia muslim. Orang Eropa menemukan dunia melalui lautan dan daratan, bukan hanya sekadar rencana lahirnya ide-ide gemilang dan sumber kemakmuran ekonomi atau misi suci keagamaan dengan semboyan gold, gospel, dan glory, tetapi juga sebuah petualangan untuk mencari ilmu.

Berangkat dari pengaruh besar yang disuntikkan oleh kebudayaan muslim di samping tentu saja proses internal yang berlaku dalam kebudayaan Barat sendiri, telah melahirkan berbagai gerakan revolusi yang berhubungan erat dengan semangat untuk terus melakukan berbagai kajian dan terobosan di bidang ilmu. Penguasaan yang mumpuni di bidang ilmu inilah yang kemudian diyakini memainkan peranan penting dalam mengantarkan peradaban Barat untuk menjadi superior sebagaimana dahulu juga berlaku pada peradaban muslim.

\footnotetext{
${ }^{24}$ Umar A.M. Kasule, "Revolusi Ilmu Pengetahuan: Kenapa Terjadi di Eropa Bukan di Dunia Muslim?”, dalam Majalah Pemikiran dan Peradaban Islam ISLAMIA, Tahun I No. 3 / September-Nopember 2004, h. 90-91.
} 
Penguasaan pada bidang ilmu sains inilah sebagaimana dijelaskan Cemil Akdogan, yang menjadi rahasia sejati kemajuan Barat. Ia merupakan kerja abstrak yang berbuah pada kemampuan teknologi. Secara salah kaprah, bangsa-bangsa Islam menurut Akdogan mengidentifikasi peradaban Barat dengan piranti teknologi seperti kendaraan, alat-alat listrik, televisi, radio, telepon, pesawat, senjata nuklir dsb., dan kemudian mencoba mengimitasinya yang pada akhirnya merugikan diri sendiri. Kemampuan teknologi Barat adalah aplikasi pengetahuan ilmiah. Tanpa penguasaan landasan ilmiah, hanya memproduksi piranti-piranti teknologi melalui imitasi sangatlah berisiko. Apabila hal ini dipaksakan, maka bangsa-bangsa muslim tidak akan pernah dapat berhasil mengambil alih kepemimpinan ilmiah dari Barat, supremasi Barat dalam teknologi berbasis sains akan terus berlanjut. ${ }^{25}$

Dengan penguasaan dan pemanfaatan teknologi yang berbasis sains ini, kemajuan Barat berkembang dengan sangat pesat tanpa dapat dibendung lagi. Dewasa ini, bahkan para ilmuwan mereka sering kali mempengaruhi kebijakan-kebijakan pemerintahan ataupun industriindustri, dan juga mendapatkan posisi-posisi tinggi pada hampir setiap cabang pemerintahan. Sebagai misal di Amerika Serikat, mereka memberikan nasihat kepada Presiden dan Kongres, khususnya tentang isuisu penting yang bersifat ilmiah. ${ }^{26}$

\section{Islam dalam Perkembangan Peradaban Modern}

\section{Krisis Ilmu di Dunia Muslim}

Seolah mengikuti hukum sejarah, setelah beberapa abad berada di puncak memimpin peradaban dunia, umat Islam memasuki fase kemunduran. Bahkan berikutnya, nasib tragis menimpa umat yang peradabannya pernah menjadi mercusuar dunia dengan supremasi dan superioritas mereka di bidang ilmu. Mereka mengalami kehinaan dan ketertindasan dalam penjajahan. Kemiskinan dan kebodohan menjadi karakteristik yang sering dilekatkan padanya. Nurcholish Madjid

\footnotetext{
${ }^{25}$ Lihat Cemil Akdogan, "Asal-usul Sains Modern dan Kontribusi Islam” (Part I), dalam Majalah Islamia, Tahun 1 No. 4/Januari-Maret 2005, h. 93-94.
} 
memberikan ilustrasi tentang realitas yang menyedihkan dari umat Muhammad ini:

Dewasa ini dunia Islam praktis merupakan kawasan bumi yang paling terkebelakang di antara penganut agama-agama besar. Negeri-negeri Islam jauh tertinggal oleh Eropa Utara, Amerika Utara, Australia, dan Selandia Baru yang Protestan; oleh Eropa Selatan dan Amerika Selatan yang Katolik Romawi; oleh Eropa Timur yang Katolik Ortodoks; oleh Israel yang Yahudi; oleh India yang Hindu; oleh Cina (giant dragon), Korea Selatan, Taiwan, Hongkong, dan Singapura (little dragon) yang BudhisKonfusianis; oleh Jepang yang Budhis Taois; dan oleh Thailand yang Budhis. Praktis tidak satu pun agama besar di muka bumi ini yang lebih rendah kemajuan ilmu dan teknologi (iptek)-nya daripada Islam. Dengan perkataan lain, di antara semua penganut agama besar di muka bumi ini, para pemeluk Islam adalah yang paling rendah dan lemah dalam hal sains dan teknologi. ${ }^{27}$ Kondisi umat Islam tersebut pasca tragedi W'TC (World Trade Center) di Amerika Serikat pada 11 September 2001, semakin memprihatinkan. Karena Islam, sebagai salah satu agama yang memiliki pemeluk terbesar di dunia 'seolah' menjadi 'tersangka utama' berbagai gerakan kekerasan yang disebut terorisme dan menjadi musuh peradaban dunia dan kemanusiaan. Kondisi aktual umat Islam ini tampaknya semakin mempertegas sinyalemen yang dikemukakan Shabbir Akhtar bahwa dahulu orang (Barat) berkata, "Islam adalah agama terbaik dengan penganut terburuk, sesudah Salman Rushdie banyak yang berkata, Islam adalah agama terburuk dengan para penganut yang terburuk pula." ${ }^{28}$

${ }^{26}$ Lihat Cemil Akdogan, "Asal-usul Sains Modern dan Kontribusi Islam” (Part II), dalam Majalah Islamia, Tahun 1 No. 5/April-Juni 2005, h. 84.

${ }^{27}$ Lihat Nurcholish Madjid, Kaki Langit Peradaban Islam (Paramadina: Jakarta, 1997), h. $21-22$.

${ }^{28}$ Salman Rushdi adalah penulis novel The Satanic Verses, yang isinya sangat provokatif dan menghina Nabi, dan kemudian memunculkan fatwa mati dari pemimpin revolusi Iran, Ayatullah Khomeini dan pembakaran novel tersebut oleh kalangan muslim di Inggris, sehingga menimbulkan pandangan bahwa Islam itu anti ilmu. Ziauddin Sardar menceritakan masamasa yang tidak nyaman hidup dalam komunitas Barat, yaitu ketika secara pribadi, ungkap Sardar dia sangat membenci novel tersebut, yang menghantam semua keyakinan yang dia pegangi, tetapi lahirnya fatwa Khomeini alih-alih bisa menyelesaikan masalah, malah semakin memperburuk citra Islam di Barat sebagai agama yang jauh dari tradisi ilmiah, tidak mampu menjawab suatu gugatan, melainkan dengan sebuah fatwa. Lihat Ziauddin Sardar, Desperately 
Melihat realitas yang cukup memprihatinkan dari umat Islam dewasa ini, yang diyakini bersumber pada inferioritas umat Islam di bidang ilmu, maka pertanyaan yang sering dilontarkan, apakah yang menyebabkan kemunduran umat Islam di bidang ilmu tersebut? Ada banyak jawaban dan pandangan tentang penyebab kemunduran umat Islam. Berikut ini sebagian analisis yang dikemukakan oleh beberapa ahli yang mengkaji tentang perkembangan ilmu di dunia muslim.

Profesor Abdul Hamid Sabra, pakar sejarah sains dari Universitas Harvard, menyatakan bahwa kemunduran hanyalah salah fase dari perkembangan ilmu di dunia muslim, yang disebut sebagai appropriasi. Sebelum itu telah ada fase-fase yang mendahului, yakni fase pertama berupa fase peralihan atau akuisisi, yaitu proses masuknya sains Yunani ke wilayah Islam sebagai tamu yang diundang, dan bukan sebagai penjajah. Fase kedua, yaitu kelanjutan fase pertama, berupa penerimaan atau adopsi. Fase yang ketiga, yaitu fase asimilasi dan naturalisasi, yang merupakan fase kematangan, yang berlangsung sekitar 500 tahun lamanya. Baru kemudian selanjutnya fase yang keempat, yaitu appropriasi. Pada tahap ini, aktivitas saintifik mengalami reduksi karena lebih diorientasikan untuk memenuhi kebutuhan praktis. Wilayah dan peran sains menyempit menjadi sekadar pelayan agama. ${ }^{29}$

Pandangan Sabra yang menyatakan adanya penyempitan wilayah dan peran sains sebagai pelayan agama ini, dipertegas lagi oleh David A. King, seorang ahli sejarah astronomi Islam dari Universitas Frankfurt, yang menilai bahwa posisi aritmatika di dunia muslim dianggap penting karena merupakan alat yang berguna untuk menghitung pembagian harta warisan. Sementara itu, astronomi dan geometri (trigonometri) diajarkan untuk membantu menetapkan jadwal shalat dari waktu ke waktu dan menentukan arah kiblat. ${ }^{30}$

Adapun David C. Lindberg menyebut ada tiga faktor utama yang menyebabkan kemunduran sains di dunia muslim. Pertama, oposisi kaum

Seeking Paradise: Kisah Perjalanan Hidup Seorang Muslim Skeptis (Jakarta: PT Diwan Publishing, 2006).

${ }^{29}$ Lihat A.E. Sabra, "The Appropriation and Subsequent Naturalization of Greek Science in Medieval Islam: A Preliminary Statement”, dalam jurnal History of Science 1987, h. 223 43.

${ }^{30}$ Lihat David A. King, Astronomy in the Service of Islam (Aldershot: Variorum, 1993). 
konservatif. Pertentangan kaum konservatif terhadap sains dan saintis semakin lama semakin gencar, ditunjukkan antara lain pada kasus "pembakaran" buku-buku sains dan filsafat yang terjadi di Cordova. Kedua, krisis ekonomi dan politik. Harus diakui bahwa krisis ekonomi dan instabilitas politik sangat berpengaruh terhadap sains. Konflik berkepanjangan yang sering kali disertai dengan perang saudara telah mengakibatkan disintegrasi, krisis militer dan hancurnya ekonomi. Padahal jelas Lindberg, perkembangan ilmu mensyaratkan adanya stabilitas, kemakmuran, dan patron. Ketiga pilar ini mulai absen di dunia Islam menjelang abad ke-13 Masehi. Semua ini diperparah lagi dengan serangan tentara salib (1099), pembantaian riconquista di Spanyol (1065-1248) yang memakan ratusan ribu korban, dan invasi pasukan Mongol yang berhasil menduduki Baghdad pada 1258 $M$ yang selain menimbulkan korban jiwa, juga mengakibatkan perpustakaan dan berbagai fasilitas riset dan pendidikan porak-poranda. Ekonomi pun lumpuh dan sebagai akibatnya sains berjalan tertatih-tatih. Ketiga, keterasingan dan marginalisasi. Sains di dunia Islam tidak bisa maju karena statusnya memang selalu dipinggirkan atau dianaktirikan. Sains tidak pernah secara resmi diakui sebagai salah satu mata pelajaran atau bidang studi tersendiri. Pengajaran sains hanya dilakukan dengan cara menyelipkan pada subjek lainnya. Selain itu, para saintis banyak yang bekerja sendiri-sendiri di laboratorium milik pribadi, dan tidak ada lembaga yang khusus menampung mereka. ${ }^{31}$

Adapun Toby E. Huff menyatakan bahwa kemunduran sains lebih disebabkan oleh masalah-masalah sosial budaya. Menurutnya, iklim sosial kultural politik saat itu gagal dalam menumbuhkan semangat universalisme dan otonomi kelembagaan di satu sisi, dan membiarkan partikularisme dan elitisme berkembang biak. Di sisi lain, tidak skeptisisme yang terorganisir dan dedikasi yang murni juga mempengaruhi perkembangan sains di dunia muslim. ${ }^{32}$

${ }^{31}$ David C. Linberg, The Beginnings of Western Science: The European Scientific Tradition in Philosophical, Religious, and Institutional Context, 600 B.C. to A.D. 1450 (Chicago: The University of Chocago Press, 1992), h. 180-182. Lihat juga Syamsuddin Arif, "Sains di Dunia Islam: Telaah Historis-Sosiologis" dalam Majalah ISLAMLA Tahun II No. 6/Juli-September 2005, h. 86-94.

${ }^{32}$ Toby E. Huff, The Rise of Early Modern Science: Islam, China, and the West (Cambridge: Cambridge University Press, 1993), h. 208-212. 
Pendapat lain dikemukakan oleh Pervez Hoodbhoy, seorang pakar nuklir dari Pakistan, yang menyebut bahwa teologi Asy'ari sebagai salah satu penyebab kemunduran sains. Menurutnya, doktrin teologi ini menjadikan kaum muslim menjadi fatalistik, tidak berpikir rasional dan cenderung bersikap pasif dalam menyikapi fenomena dan realitas. Lebih jauh lagi Hoodbhoy menuduh al-Ghazali sebagai orang yang bertanggung jawab menghancurkan bangunan sains di dunia Islam. ${ }^{33}$

Selain pendapat-pendapat di atas, ada juga yang menghubungkan kemunduran sains dengan sufisme. Seiring dengan kemajuan peradaban Islam saat itu, muncul berbagai gerakan moral spiritual yang dipelopori oleh kaum sufi. Intinya adalah penyucian jiwa dan pembinaan diri secara lebih intensif dan terencana. Gerakan-gerakan tersebut kemudian mengkristal menjadi tarekat-tarekat dengan pengikut yang kebanyakan orang awam. Popularisasi tasawuf inilah yang dianggap bertanggung jawab melahirkan sufi-sufi palsu dan menumbuhkan sikap irasional di kalangan masyarakat. Mereka lebih tertarik kepada aspek-aspek mistik supranatural seperti keramat, kesaktian, keajaiban, dan sebagainya ketimbang pada aspek 'ubudiyyah dan akhlaknya. Karena tidak bertolak dari pengalamanpengalaman aktual ummah, tegas al-Faruqi, maka pemikiran muslim menjadi konservatif, literal di dalam hukum, spekulatif di dalam penafsiran dan worldview Alquran, esoterik di dalam sains-sains kealaman. ${ }^{34}$

Sementara itu, Abdus Salam, seorang saintis muslim ternama yang pernah meraih hadiah Nobel Fisika lebih melihat faktor internal sebagai penyebab kemunduran umat Islam, khususnya pada bidang sains. Menurutnya, umat Islam cenderung bersifat acuh dan menutup diri terhadap perkembangan yang terjadi di luar dunia muslim. Sikap acuh ini mendorong ke arah isolasi. Tradisi al-Kindi untuk memperoleh pengetahuan dari mana pun di dapat dilupakan, masyarakat ilmiah muslim tidak mencari kontak dengan dunia Barat yang pada saat itu justru mulai menciptakan sains. ${ }^{35}$

\footnotetext{
${ }^{33}$ Pervez Hoodbhoy, Islam and Science: Religious Orthodoxy and the Battle for Rationality (London and New Jersey: Zed Books, 1991), h. 104-107 dan 120.

${ }^{34}$ Isma'il Raji al Faruqi, Islamisasi Pengetahuan, terj. Anas Mahyuddin (Bandung: Pustaka, 2003), h. 52.

${ }^{35}$ Lihat Abdus Salam, Sains dan Dunia Islam, h. 12-13.
} 
Melihat berbagai pendapat yang dikemukakan oleh para penulis di atas, dapat disimpulkan bahwa kemunduran ilmu yang terjadi di dunia Islam bukanlah disebabkan oleh satu faktor yang tunggal, tetapi ada banyak variabel yang menyertainya. Faktor tersebut ada yang berasal dari dunia muslim sendiri, yaitu berupa hilangnya ghirah atau semangat keilmuan, dan kondisi internal muslin yang rapuh akibat berbagai serangan dari pihak luar, yang membuat umat Islam lebih suka untuk bersikap defensif, mempertahankan apa yang sudah ada, dan menutup "pintu ijtihad" yang mungkin akan dapat menyebabkan instabilitas politik, yang memang sudah mulai goyang, ataupun faktor dari luar atau eksternal berupa peperangan, serangan, atau kolonialisasi dari bangsa lain ke dunia muslim.

Dengan berandai-andai, Cemil Akdogan, profesor sejarah sains di ISTAC-IIUM, menyatakan bahwa jikalau umat Islam - yang menurutnya adalah pioner sains modern - tidak berperang di antara sesama mereka, dan jika tentara Kristen tidak mengusirnya dari Spanyol, dan jika orangorang Mongol tidak menyerang dan merusak bagian-bagian dari negerinegeri Islam pada abad ke-13, mereka akan mampu menciptakan seorang Descartes, seorang Gassendi, seorang Hume, seorang Copernicus, dan seorang Tycho Brahe, karena kita telah menemukan bibit-bibit filsafat mekanika, empirisisme, elemen-elemen utama dalam heliosentrisme, dan instrumen-instrumen Tycho Brahe dalam karya-karya al-Ghazali, Ibnu alShatir, para astronom pada observatorium Maragha, dan karya-karya Taqiyuddin. ${ }^{36}$

\section{Stagnasi Ilmu-ilmu Islam}

Kemunduran umat Islam yang ditandai dengan keterlenaan umat Islam dengan apa yang sudah mereka miliki, dan kepuasaan dengan hanya menikmati karya-karya yang telah diwariskan oleh para pendahulu mereka, yang kemudian membuat mereka stagnan dan tidak membuat kemajuan apa-apa, baru belakangan mulai disadari setelah umat Islam berinteraksi dengan dunia Barat, yang sudah melesat maju meninggalkan "gurunya", yakni umat Islam sendiri sedemikian jauh, dan seolah tidak bisa lagi terkejar.

\footnotetext{
${ }^{36}$ Lihat Cemil Akdogan, "Asal-usul Sains Modern dan Kontribusi Islam”, dalam Majalah Islamia, Thn. 1 No. 4/Januari-Maret 2005, h. 94.
} 
Gambaran tentang perkembangan ilmu (sains) di dunia muslim dipotret dengan sangat menarik dalam jurnal sains Nature, edisi 2 Nopember 2006. Meski ada beberapa negara muslim yang relatif dianggap maju dalam pengembangan sains dan teknologi, namun secara umum disimpulkan bahwa negara-negara muslim tidak memiliki perhatian yang cukup memadai terhadap perkembangan sains. Bahkan, anggaran untuk riset dan pengembangan sangat rendah apabila dibandingkan dengan ratarata anggaran global. Selain itu, data-data riset yang dimiliki pada 57 negaranegara muslim yang tergabung dalam organisasi konferensi Islam (OKI) juga tidak tidak jelas dan akurat. ${ }^{37}$

Fakta keterpurukan umat Islam di berbagai bidang ini sebenarnya sudah lama menjadi perhatian dari para intelektual muslim dan mereka berupaya mencari akar permasalahannya. Muhammad Abduh misalnya sebagai salah satu ikon pembaru Islam di abad modern, menyatakan dengan tegas bahwa ketertinggalan umat Islam di bidang ilmu adalah akibat sikap statis pada diri mereka:

Secara ajaran, Islam sarat dengan semangat yang menggugah ilmu. Ketertinggalan umat Islam, adalah lebih karena sikap mereka yang statis (jumud). Agama selalu berjalan berdampingan dengan akal untuk mengarungi lautan ilmu, menjelajahi permukaan bumi dan naik ke lapisan langit tinggi, untuk menyelidiki tanda-tanda kekuasaan Allah dan rahasia ciptaan-Nya. Manakala paham keagamaan membeku dan penuntutpenuntut ilmu sudah tidak giat lagi, maka itu pun turut membeku pula. ${ }^{38}$

Bersamaan dengan mulai mundurnya peradaban Islam tersebut, Eropa (baca: Barat) mengalami kebangkitan. Pada masa ini, buku-buku filsafat dan ilmu karangan dan terjemahan filosof Islam seperti al-Kindi, al-Farabi, Ibnu Sina, dan Ibnu Rusyd diterjemahkan ke dalam bahasa Latin, yang pada saat itu merupakan bahasa kebudayaan bangsa-bangsa Eropa.

Secara perlahan Barat membangun peradabannya melalui berbagai seri perubahan revolusioner seperti revolusi keilmuan, revolusi Perancis, revolusi industri, profesionalisasi ilmu, interaksi rapat antara ilmu dan

\footnotetext{
${ }^{37}$ Lihat www.nature.com (diakses pada 1 Februari 2007).

${ }^{38}$ Lihat Syekh Muhammad Abduh, Ilmu dan Peradaban Menurut Islam dan Kristen, terj. Mahyiddin Syaf \& A. Bakar Usman (Bandung: CV Diponegoro, 1978), h. 121.
} 
teknologi, dan revolusi-revolusi abad ke-20 dalam ilmu yang berkesinambungan, bukan saja mempengaruhi dunia Barat sendiri, tetapi juga dunia secara keseluruhan.

Di tengah hegemoni dan dominasi peradaban Barat modern, kesadaran akan ketertinggalan umat Islam menjadi keprihatinan mendalam pada diri para inteletual muslim kontemporer. Lemahnya penguasaan pada ilmu dan stagnasi ilmu-ilmu Islam adalah faktor terbesar dan menjadi kunci dari ketertinggalan ini. Para pemikir seperti Sayyid Hossein Nasr, ${ }^{39}$ Fazlur Rahman, ${ }^{40}$ Ismail Razi al-Faruqi, ${ }^{41}$ dan Syed Muhammad Naquib al-Attas ${ }^{42}$ adalah di antara mereka yang prihatin dan sangat bersemangat dalam upaya mencari solusi ketertinggalan umat Islam di bidang yang satu ini.

\section{Penutup}

Secara lebih mendasar, ikhtiar untuk memajukan dunia muslim dalam beberapa dekade terakhir ini telah melahirkan apa yang disebut dengan kebangkitan kembali dunia Islam. Kebangkitan kembali Islam (Islamic resurgence) merupakan suatu gerakan yang mengacu pada pandangan dari kaum muslim sendiri bahwa Islam menjadi penting kembali. Islam dikaitkan dengan masa lalunya yang gemilang, sehingga masa lalu tersebut mempengaruhi pemikiran kaum muslim sekarang; Islam dipandang sebagai alternatif, dan karena itu dianggap ancaman bagi pandangan hidup atau ideologi lain yang sudah mapan, khususnya ideologi-ideologi Barat.

Satu karakter menonjol dari kecenderungan yang dominan dari kebangkitan Islam adalah keyakinan kuat bahwa masyarakat harus diorganisir atas dasar Alquran dan Sunnah. Ini berarti nilai-nilai, prinsip-prinsip, aturan-

${ }^{39}$ Lihat Science and Civilization in Islam (Cambridge: Harvard University Press, 1968); Islamic Science: an Illustrated Study (London: World of Islam Festival Publishing Co. Ltd., 1976); Knowledge and the Sacred (New York: Crossroad, 1989).

${ }^{40}$ Lihat Islam (Chicago: The University of Chicago Press, 1979); Islam and Modernity: the Transformation of an Intellectual Tradition (Chicago: The University of Chicago Press, 1982).

${ }^{41}$ Lihat Islamization of Knowledge: General Principles and Workplan (Washington: International Institute of Islamic Thought-IIIT, 1982); Taubid: It's Implications for Thought and Life (Washington: International Institute of Islamic Thought-IIIT, 1982).

${ }^{42}$ Lihat Islam and Secularism (Kuala Lumpur: ABIM, 1978); Islam and The Philosophy of Science (Kuala Lumpur: ISTAC, 1989); The Concept of Education in Islam: A Framework for an Islamic Pbilosoby of Education (Kuala Lumpur: ISTAC, 1991). 
aturan, dan regulasi yang terkandung dalam Alquran dan Sunnah harus ditegakkan dalam kehidupan politik, ekonomi, budaya, pendidikan, hukum, pemerintahan, dan tentu saja terutama di bidang ilmu, yang dalam hal ini umat Islam tertinggal jauh oleh Barat.

Selain itu, para pemikir muslim kontemporer memiliki pandangan beragam terhadap ilmu modern yang merupakan produk Barat. Pada satu sisi ada kelompok yang memujanya sedemikian rupa, dan mengharuskan umat Islam untuk meniru Barat apabila juga ingin maju, pada sisi lain, ada tampil sekelompok ilmuwan yang kritis terhadap Barat, dengan menyatakan bahwa ilmu Barat selain memiliki kontribusi dalam memajukan dunia, pada saat yang sama juga memiliki peran yang besar dalam melahirkan berbagai problema dan krisis kemanusiaan manusia modern. Hal ini terjadi dikarenakan pengabaiannya kepada yang sakral (Tuhan) dan penolakannya terhadap wahyu sebagai salah satu sumber ilmu []

\section{DAFTAR PUSTAKA}

Arifin, Syamsul dkk, 1996, Spritualisasi Islam dam Peradaban Masa Depan, (Yogyakarta: Sipress).

Asmuni, Yusran, 1996, Dirasah Islamiyah II Pengantar Studi Sejarah Kebudayaan Islam \& Pemikiran, (Jakarta: PT RajaGrafindo Persada).

Corbin, Henry, 1993, History of Islamic Philosophy, (London: Kegan paul International in association wlth Islamic Publications for the Institute of Ismaili Studies).

Fakhry, Majid, 2001, Sejarah Filsafat Islam Sebuah Peta Kronologis, penerjemah Zaimul Am, (Bandung: Mizan).

Ghulsyani, Mahdi, 1991, Filsafat Sains Menurut al Qur'an, penerjemah Agoes Effendi, (Bandung: Mizan).

Hanafi, Ahmad, 1995, Pengantar dan Sejarah bukum Islam, (Jakarta: Bulan Bintang).

Khaldun, Ibn, 2001, Muqaddimah, penerjemahAhmadie Thoha, (Jakarta: Pustaka Firdaus). 
Leaman, Oliver, 2001, Pengantar Filsafat Islam Sebuab Pendekatan Tematis, penerjemah Musa Kazhim dan Arif Mulyadi, (Bandung: Mizan).

Madkour, Ibrahim, 1995, Aliran dan Teori Filsafat Islam, penerjemah Yudian W. Yasmin, (Jakarta: Bumi Aksara).

Nasution, Harun, 1986, Islam Ditinjau Dari Berbaga Aspeknyas Jilid II, (Jakarta: UI-Press).

—_, 1995, Filsafat dan Mistisisme Dalam Islam, (Jakarta: Bulan Bintang).

Rahman, Fazlur, 1985, Islam and modernity: Transformation an Intelectual tradition, penerjemah ahsin Muhammad, (Bandung: Pustaka).

Shihab, M. Quraish, 1995, Membumikan al Qur'an: Fungsi dan Peran Wabyu Dalam Kehidupan Masyarakat, (Bandung: Mizan). 